\title{
Platelet Function Determined by Flow Cytometry: New Perspectives?
}

Sofia Ramström, Anna Södergren, Nahreen Tynngård and Tomas Lindahl

\author{
Linköping University Post Print
}

\section{Tweet}

N.B.: When citing this work, cite the original article.

Original Publication:

Sofia Ramström, Anna Södergren, Nahreen Tynngård and Tomas Lindahl, Platelet Function Determined by Flow Cytometry: New Perspectives?, 2016, Seminars in Thrombosis and Hemostasis, (42), 3, 268-281.

http://dx.doi.org/10.1055/s-0035-1570082

Copyright: Thieme Publishing / Georg Thieme Verlag http://www.thieme.com/

Postprint available at: Linköping University Electronic Press

http://urn.kb.se/resolve?urn=urn:nbn:se:liu:diva-126156 


\section{Platelet function determined by flow cytometry - new perspectives? \\ Sofia Ramström, $\mathrm{PhD}^{1}$ Anna Södergren, $\mathrm{MSc}^{1}$ Nahreen Tynngård, PhD ${ }^{2,3}$ Tomas L Lindahl, MD, PhD ${ }^{1,3}$}

${ }^{1}$ Department of Clinical and Experimental Medicine, Linköping University, Linköping, Sweden

${ }^{2}$ Department of Clinical Immunology and Transfusion Medicine, and Department of Clinical and Experimental Medicine, Linköping University, Linköping, Sweden

${ }^{3}$ Department of Clinical Chemistry and Department of Clinical and Experimental Medicine, Linköping University, Linköping, Sweden

Address for correspondence Sofia Ramström, PhD, Department of Clinical and Experimental Medicine, Clinical Chemistry, Faculty of Medicine and Health Sciences, Linköping University, SE58185 Linköping, Sweden (e-mail: sofia.ramstrom@liu.se)

\section{ABSTRACT}

Flow cytometry enables studies of a number of different aspects of platelet function in response to a variety of platelet agonists. This can be done using only a small volume of whole blood, and also in blood with low platelet counts. These properties, together with the increasing number of flow cytometers available in hospitals worldwide makes flow cytometry an interesting option for laboratories interested in studies of platelet function in different clinical settings. This review focuses on practical issues regarding the use of flow cytometry for platelet function testing. It provides an overview of available activation markers, platelet agonists and experimental setup issues. The review summarizes previous experience and factors important to consider in order to perform high quality platelet function testing by flow cytometry. It also discusses its current use, and possibilities and challenges for future use of flow cytometry in clinical settings.

\section{Keywords}

Blood platelets, flow cytometry, platelet activation, platelet function testing 


\section{INTRODUCTION}

Mild bleeding disorders caused by inherited platelet dysfunction are a diagnostic challenge ${ }^{1}$. At the same time, inhibition of platelet activation is of paramount importance in cardiovascular diseases. In light of this, there are multiple clinical reasons to measure platelet function. The "gold standard" since the 1960's is light transmission aggregometry on citrated platelet-rich plasma (PRP), but this method is cumbersome and results vary with the platelet count ${ }^{2}$. In addition, it requires a relatively large volume of blood and only investigates one aspect of platelet function, the aggregation potential. Improved methods for investigation of different aspects of platelet function are therefore in demand.

In flow cytometry, single cells are passed through one or more laser beams, where the light scatter (indicating cell size and granularity) and signal intensity from different fluorescently labeled markers bound to the cell can be measured. This enables studies of a number of different aspects of platelet function in response to a variety of platelet agonists. The possibility to obtain results from thousands of individual platelets in just a few seconds, and from just a few microliters of blood is also attractive, especially for pediatric patients. Another major advantage is that platelet function can be investigated in blood from patients with thrombocytopenia, as the technique does not require a certain cell count to give reliable results. Due to the versatility of flow cytometers, these instruments are now available in many hospitals for other applications. Thus, flow cytometry may be an attractive option for many laboratories wanting to perform platelet function testing.

This review focuses on practical issues regarding the use of flow cytometry for platelet function testing. It discusses its possibilities and limitations and reflects on its current and potential future use in clinical practice.

\section{METHODOLOGICAL ISSUES}

\section{Preparation of platelets}

Due to the size difference as compared to other blood cells, platelets are easily distinguishable in whole blood samples. This allows platelet analysis by flow cytometry in diluted whole blood. Although it is possible to use PRP or platelet suspensions as well, the diluted whole blood method first described by Shattil and colleagues in $1987^{3}$ offers several advantages, as it reduces the risk of pre-activation and loss of larger/denser platelet populations (during e.g. centrifugation to produce 
PRP ${ }^{4,5}$. For some assays, the presence of other blood cells is also needed, such as when plateletleukocyte aggregates are analyzed.

The most common choice for blood anticoagulation is still sodium citrate (3.2 or 3.8\%), but the use of other anticoagulants are increasing, such as hirudin, D-Phenylalanyl-L-prolyl-L-arginine Chloromethyl Ketone (PPACK) ${ }^{6}$, corn trypsin inhibitor (CTI) and other options that do not interfere with the calcium levels of the blood. Strong calcium chelators such as ethylenediaminetetraacetic acid (EDTA) should be avoided as it dissociates the fibrinogen receptor glycoprotein (GP) Illb/Illa irreversibly and thereby prevents fibrinogen binding ${ }^{7}$ (although this can also be used to create a negative control for this analysis $\left.{ }^{8}\right)$. Something worth to keep in mind when comparing results from platelets in different anticoagulants is that platelet responses seem to be higher in platelets exposed to citrate anticoagulation, despite a large dilution of the anticoagulant in the reaction mixture where platelets are activated (see Fig. 1A-C). This is not unique for flow cytometry, it has previously been reported that the potency of different GPIIb/IIla antagonists differed depending on the anticoagulant used in the assay $y^{9,10}$. In addition, an enhanced thromboxane production in conditions with low extracellular calcium levels has been suggested to cause a second wave of aggregation in response to adenosine diphosphate (ADP) in citrated plasma, something that was not observed at physiological levels of calcium ${ }^{11-13}$. The problem with thrombin inhibitors such as hirudin and PPACK is that these make it impossible to use thrombin for platelet activation. If thrombin is used, citrate anticoagulation is the common choice. Addition of the fibrin polymerization inhibitor peptide glycylL-prolyl-L-arginyl-L-proline (GPRP) ${ }^{14-17}$ to the reaction mixture is necessary if whole blood or PRP is to be used together with thrombin. With GPRP it is possible to avoid fibrin network formation, which will otherwise trap the platelets and potentially clog the flow cytometer.

For heparin as anticoagulant, there are reports stating that it either potentiates ${ }^{18}$ or inhibits $^{19}$ platelet aggregation responses, and one flow cytometry study reporting a higher platelet response when heparin and citrate was present, as compared to citrate alone ${ }^{20}$. Thus, the evidence is inconclusive to the potential effects of heparin as anticoagulant. In Fig. 1A-C, platelet responses in heparin were mostly intermediate to those in citrate and hirudin. We thus suggest that if heparinized blood is the only available option, it can be used if proper controls showing no signs of pre-activation are included and these are presented together with the results. It should also be kept in mind that the potential heparin-induced effects discussed here are completely unrelated to the dramatic immunological reaction leading to platelet binding and clearance in patients with heparininduced thrombocytopenia (HIT). 
For blood collection, the general recommendations are to use minimal stasis and a large needle (1921 gauge) to ensure a smooth blood flow and to discard the first portion of blood (at least $2 \mathrm{ml}$ ) to avoid pre-activation of platelets and inclusion of vessel wall materia| ${ }^{21,22}$. Systematic mixing (by 6-10 times full inversion) of the tube after the blood draw is important to allow rapid exposure to the anticoagulant. After that, vigorous shaking (e.g. pneumatic tube transport) or temperature shifts during transportation to the lab has to be avoided, as these procedures have been shown to cause platelet pre-activation ${ }^{23,24}$. By including a sample checking for spontaneous platelet pre-activation in the flow cytometry panel, it will be possible to find and potentially discard data that are unreliable due to pre-analytical activation of the collected platelets (discussed further below). Blood samples should be kept at room temperature prior to analysis ${ }^{22}$, and actions taken to prevent temperature fluctuations. Both refrigeration and storage at $37^{\circ} \mathrm{C}$ affect platelet function ${ }^{25}$ and should therefore be avoided.

With regards to the time from blood collection until the start of platelet function testing, not much data is available. Most published flow cytometry protocols for research state that preparation for testing was started "immediately" after blood collection. However, this is naturally difficult to achieve in clinical settings, and in worst case, differences in time between sampling and preparation in the control group and the patient material could be a possible cause of observed differences. Therefore, it is very important to standardize both blood sampling conditions and time to function testing, and to choose a time interval achievable for all samples. There are reports stating that the platelet responses during the first hour after blood collection in citrate tubes are actually lower, but to varying degrees, and that a higher and more stable response is achieved in samples 1-2 hours after blood collection ${ }^{26}$. For a clinical study, this time interval may be a more reasonable and achievable target window, but it should be validated for the specific protocol used in the study.

\section{Sample preparation}

To avoid platelet aggregation, it is necessary to dilute the blood prior to platelet activation, a dilution of 1:12-13 was used in the original whole blood protocol ${ }^{3}$. It is also important to avoid vigorous mixing (use only brief low speed vortex or finger tapping, with no mixing during activation). To check for potential platelet aggregation during the activation procedure, a simple way to get a crude estimate is to count the time it takes to achieve the selected number of platelets during acquisition in activated vs. buffer-treated samples ${ }^{27}$. Although most flow cytometer brands do not have exact volumetric dispensing, this approach will detect if a significant number of platelets are lost from the 
single platelet gate upon activation. If this is the case, the dilution, mixing or activation part of the protocol might need to be adjusted.

The "Consensus protocol for flow cytometric characterization of platelet function", published by the European Working Group on Clinical Cell Analysis ${ }^{28}$ recommends the use of a phosphate buffered saline (PBS) buffer. Addition of bovine serum albumin is suggested to prevent non-specific antibody binding. A modified Tyrode's buffer is suggested for studies of platelet activation, as it also contains glucose and magnesium. We, and others, have good experience with the HEPES buffer described by Shattil et $\mathrm{al}^{29}$, which fulfill all these criteria.

Except for cases where the intention is to study the loss of surface receptors due to internalization ${ }^{27,30}$, it is common and convenient to add the antibodies to the initial sample dilution mixture prior to activation. To minimize issues with unspecific binding, which might reduce the dynamic range of the assay, all antibodies should be titrated to find the lowest concentration needed to fully saturate a highly activated platelet sample ${ }^{31}$. This concentration is often lower than the one suggested by the manufacturer, as platelets are rarely the primary target for commercial antibodies. For studies of platelet activation, it is also absolutely essential to be able to tell where the gate dividing positive and negative platelets should be placed. Although the use of isotype controls is much discussed ${ }^{31,32}$, our experience is that an isotype control where the dilution has been based both on antibody concentration and knowledge regarding the number of fluorophores per protein (F/P ratio) usually nicely mirrors the peak in the resting sample with only buffer added, except for the right-hand shift caused by pre-activated platelets. It needs to be confirmed that this is the case, otherwise the isotype control is useless for gating. It should be noted that both the concentration and F/P ratio commonly varies between different batches of antibodies, especially for small fluorophores such as fluorescein isothiocyanate (FITC). Thus, if not stated on the inserts, this information needs to be requested from the manufacturers in order to make a good control for gating.

The plasma concentration of biologically available calcium (free ionized calcium) is approximately 1.2 $\mathrm{mM}^{33}$ and constitutes the physiological concentration of extracellular calcium for platelets. Despite this, many in vitro platelet experiments are performed in buffers without added calcium. Addition of calcium to the buffer may affect the way the platelets respond to agonists, as influx of extracellular calcium is part of the physiological response to activation ${ }^{34}$, important e.g. for generation of procoagulant platelets ${ }^{35,36}$. Fig. 1D-F shows that transformation of the fibrinogen receptor GPIIb/IIIa into its high affinity state was somewhat inhibited in the presence of extracellular calcium, perhaps related to the down regulation of GPIIb/IIla in highly activated platelets ${ }^{37}$. On the other hand, both P- 
selectin and lysosomal-associated membrane protein-1 (LAMP-1) exposure was increased in the presence of calcium, showing that even though the intracellular calcium stores are sufficient to enable granule exocytosis ${ }^{38}$, this process is enhanced in the presence of extracellular calcium. In some cases, the addition of calcium is absolutely necessary, such as when using annexin $\mathrm{V}$ to detect the exposure of phosphatidylserine (PS) ${ }^{39-41}$, or when studying the assembly of coagulation factor complexes on the platelet surface ${ }^{42}$.

\section{Identification of platelets}

As compared to standard flow cytometry settings, such as those for leukocyte analysis, platelet protocols use logarithmic scaling for forward and side scatter detectors. In addition, the standard threshold in forward scatter applied for leukocytes needs to be significantly decreased, as plateletsized particles are normally excluded as debris in standard flow cytometry protocols. The small size of platelets renders them detectable by their forward/side scatter characteristics alone, but in the clinical setting, where disturbed cells of other origins might occur, inclusion of a platelet identification marker is clearly warranted. Common antibodies used to identify platelets target GPIb, GPIX or the GPIIb/IIla complex ${ }^{43}$. However, in the latter case, the antibody used must be able to bind both the active and resting form of the receptor and not interfere with binding of fibrinogen/conformation sensitive antibodies, if such markers are also included in the protocol. Platelets can then be identified by fluorescence from the identification marker together with one of the scatter parameters, collecting data from at least 5,000-10,000 platelets. Subsequent gating to exclude non-single events is recommended as a next step. If these events are frequent and caused by co-incidence ${ }^{44}$, where multiple particles pass the laser together, further dilution may help.

One potentially interesting feature in the platelet activation response is the release of platelet microparticles upon activation. Many reports have been published where microparticles formed in vivo are detected, and recent reviews report findings in numerous pathological conditions ${ }^{45,46}$. As this review focuses on platelet function testing, studies of microparticles alone will not be discussed. However, for all types of studies on microparticles, it is important to note that the use of beads for size determination is not accurate, as the refractive indexes of polystyrene beads and cell fragments differ ${ }^{47}$. Due to antigen depletion on smaller sized particles, markers with low surface density may not be detectable on microparticles by flow cytometry ${ }^{48}$. There is also a lower limit for the size of particles possible to detect by flow cytometry, and many particles fall below this limit (the "iceberg theory") or will be counted together as one larger particle ("swarm detection") ${ }^{49-51}$. Thus, the 
majority of detected particles with standard protocols have been suggested to be "smaller platelets" rather than microparticles ${ }^{52}$. However, the use of a fluorescence threshold on a highly expressed marker (e.g., GPIIb/IIIa) instead of a scatter threshold enables detection of smaller platelet-derived particles ${ }^{53,54}$. It is also to be noted that separation of particles based on their size is better accomplished using forward scatter on some brands of flow cytometers, while others brands give better size separation using the side scatter parameter ${ }^{55}$.

\section{Platelet activation markers}

For diagnosis of patients with mild bleeding disorders, analysis of expression of platelet surface glycoproteins is essential. Recent guidelines suggest analysis of GPIIb (CD41, integrin allb), GPIIla (CD61, integrin $\beta 3$ ), GPIba (CD42b), and GPIX (CD42a) as a first step and GPla/lla ( $\alpha 2 \beta 1)$, GPIV, and GPVI as a second step ${ }^{56}$. However, as this review focuses on tests of platelet function, receptor level tests will not be further discussed here. As the surface expression of many of these receptors change upon platelet activation ${ }^{57}$, these tests should not be performed on activated platelets.

Table 1 summarizes different platelet activation events and markers used to detect these. Directly labeled antibodies towards many of these markers are now commercially available, enabling the setup of more advanced protocols including several markers in the same tube, which is advantageous to reduce the number of tubes if many platelet agonists are to be tested. To minimize problems due to spectral overlap, efforts to choose fluorophores with minimal spectral overlap, careful titration of antibodies and proper compensation (potentially using capture beads if the antigen expression is low even on strongly activated platelets) are important issues to consider in the protocol setup ${ }^{32}$. Also note that compensation values obtained for platelets do not always match what is commonly reported for larger cells. To determine the boundary between positive and negative platelets, both properly chosen isotype controls and fluorescence-minus-one (FMO) controls are useful ${ }^{31,32}$. The gate is usually placed to get $1-2 \%$ positive platelets in the isotype sample ${ }^{28}$. In some cases, such as markers for activated GPIIb/IIla and annexin V as marker for PS exposure, binding of the marker can be prevented by other means (EDTA treatment ${ }^{8}$ or absence of calcium, respectively), making it possible to create a negative control without the use of isotype antibodies.

Table 1: Platelet activation events and markers to detect these. Markers not specific for one type of granule are shown in italics. 


\begin{tabular}{|c|c|c|c|}
\hline Activation event & $\begin{array}{l}\text { Marker(s) with } \\
\text { references. }\end{array}$ & $\begin{array}{l}\text { Other names, } \\
\text { remarks }\end{array}$ & $\begin{array}{l}\text { Possible } \\
\text { negative } \\
\text { control(s) }\end{array}$ \\
\hline $\begin{array}{l}\text { Fibrinogen receptor } \\
\text { GPIIb/IIla activation }\end{array}$ & $\begin{array}{l}\text { PAC- }{ }^{29}, \text { LIBS/RIBS-specific } \\
\text { antibodies }^{58-60 / 61-63} \\
\text { fluorescent fibrinogen } \\
\text { anti-fibrinogen antibodies }\end{array}$ & $\begin{array}{l}\text { GPIIb/IIIa = } \alpha \operatorname{IIb} \beta 3, \\
\text { CD41/61 }\end{array}$ & $\begin{array}{l}\text { EDTA-treated } \\
\text { platelets, isotype } \\
\text { control }\end{array}$ \\
\hline $\begin{array}{l}\text { Collagen receptor GPIa/lla } \\
\text { activation }\end{array}$ & $\begin{array}{l}\text { Antibody detecting } \\
\text { conformational change }{ }^{66}\end{array}$ & $\begin{array}{l}\text { GPla } / I l a=\alpha 2 \beta 1, \\
\text { CD49/CD29 }\end{array}$ & Isotype control \\
\hline Alpha granule exocytosis & $\begin{array}{l}\text { P-selectin }{ }^{67-69}, \mathrm{CD} 40 \mathrm{~L}^{70}, \\
\text { thrombospondin } \\
31,72 / G M P- \\
33^{73,74} \text {, multimerin }{ }^{75,76}\end{array}$ & $\begin{array}{l}\text { P-selectin = CD62P, } \\
\text { GMP140, PADGEM } \\
\text { CD40L = CD154 } \\
\text { GMP-33 = N- } \\
\text { terminal fragment } \\
\text { of } \\
\text { thrombospondin }{ }^{73}\end{array}$ & Isotype control \\
\hline Dense granule exocytosis & $\begin{array}{l}\text { Mepacrine staining }{ }^{77-79} \\
C D 63^{80}, L^{2} \text { PM }-2^{81,82}\end{array}$ & $\begin{array}{l}\text { CD63 = LIMP, LAMP- } \\
\text { 3, granulophysin } \\
\text { LAMP-2 = CD107b }\end{array}$ & $\begin{array}{l}\text { Non-labelled } \\
\text { platelets } \\
\text { (mepacrine), } \\
\text { isotype control }\end{array}$ \\
\hline Lysosomal exocytosis & $\begin{array}{l}\text { LAMP-1 }^{84,85},{\text { LAMP }-2^{81,82}} \\
C D 63^{80}\end{array}$ & LAMP-1 = CD107a & Isotype control \\
\hline PS exposure & $\begin{array}{l}\text { Annexin } \mathrm{V}^{39-41,86} \text {, } \\
\text { lactadherin }\end{array}$ & $\begin{array}{l}\mathrm{Ca}^{2+} \text { is required for } \\
\text { annexin } \mathrm{V} \text { binding }\end{array}$ & $\begin{array}{l}\text { Sample without } \\
\text { calcium (annexin } \\
\text { V) /resting } \\
\text { platelets } \\
\text { (lactadherin) }\end{array}$ \\
\hline Coagulation factor binding & $\begin{array}{l}\text { Factor } \mathrm{V} / \mathrm{Va}^{90,91}, \mathrm{X} / \mathrm{Xa}^{92}, \\
\mathrm{VIII}^{93}\end{array}$ & $\begin{array}{l}\mathrm{Ca}^{2+} \text { is required for } \\
\text { coagulation factor } \\
\text { complex } \\
\text { formation }{ }^{42} \text {. }\end{array}$ & Isotype control \\
\hline $\begin{array}{l}\text { Platelet vesiculation } \\
\text { (microparticle formation) }\end{array}$ & $\begin{array}{l}\text { Antibodies towards } \\
\text { surface receptors (e.g. }\end{array}$ & $\begin{array}{l}\text { Better detected } \\
\text { with threshold on }\end{array}$ & Resting platelets \\
\hline
\end{tabular}




\begin{tabular}{|c|c|c|c|}
\hline & $\begin{array}{l}\text { GPIIb, GPIIla, GPIb, GPIX) } \\
\text { or annexin V/lactadherin }{ }^{53} \\
\text { in combination with size } \\
\text { characteristics }\end{array}$ & $\begin{array}{l}\text { fluorescence } \\
\text { instead of scatter. }\end{array}$ & \\
\hline $\begin{array}{l}\text { Intracellular } \\
\text { phosphorylation events }\end{array}$ & VASP $^{94}$ & $\begin{array}{l}\text { Designed to } \\
\text { measure the } \\
\text { function of the } \\
\text { platelet ADP } \\
\text { receptor P2Y } 12 \\
\text { (more discussed } \\
\text { below). }\end{array}$ & \\
\hline $\begin{array}{l}\text { Changes in intracellular } \\
\text { calcium levels }\end{array}$ & Fluo- $3^{95}$, Fluo- $4^{96}$, Indo- $1^{97}$ & $\begin{array}{l}\text { Ratiometric } \\
\text { measurements are } \\
\text { possible by } \\
\text { combining dyes } \\
\text { with Fura Red }{ }^{96} \text {. }\end{array}$ & Resting platelets \\
\hline $\begin{array}{l}\text { Changes in mitochondrial } \\
\text { membrane potential }\end{array}$ & $\begin{array}{l}\text { A variety of probes are } \\
\text { available, based on e.g. } \\
\text { carbocyanine (e.g. JC-1), } \\
\text { rhodamine (e.g. TMRM) } \\
\text { and rosamine (e.g. } \\
\text { CMXRos) } \\
\text { 98,99. }\end{array}$ & & $\begin{array}{l}\text { Resting platelets } \\
\text { (for intact } \\
\text { membrane), } \\
\text { FCCP/CCCP- } \\
\text { treated platelets } \\
\text { (for fully } \\
\text { depolarized } \\
\text { membrane) }\end{array}$ \\
\hline
\end{tabular}

ADP - adenosine diphosphate, $\mathrm{Ca}^{2+}$ - Calcium, $\mathrm{CCCP}$ - carbonyl cyanide 3-chlorophenylhydrazone, $\mathrm{CD}$

- cluster of differentiation, CD40L - CD40 ligand, CMXRos - chloromethyl-X-rosamine, EDTA -

ethylenediaminetetraacetic acid, FCCP - carbonyl cyanide-4-trifluoromethoxyphenylhydrazone, GMP

- granule membrane protein, GP - glycoprotein, JC-1 - 5,5",6,6"-tetrachloro-1,1",3,3"-

tetraethylbenzimidazolylcarbocyanine iodide, LAMP - lysosomal associated membrane protein,

LIBS/RIBS - Ligand/receptor-induced binding site, LIMP - lysosomal integral membrane protein,

PADGEM - platelet activation dependent granule-external membrane protein, PS -

phosphatidylserine, TMRM - tetramethylrhodamine methyl ester, VASP - vasodilator-stimulated phosphoprotein. 


\section{Alternative ways to test platelet function by flow cytometry}

Other options to study platelet activation using flow cytometry includes the agonist-induced formation of platelet microaggregates, detectable by residual platelet counting ${ }^{101}$, the adhesion of platelets to protein-coated polystyrene beads ${ }^{102}$, and the formation of platelet-leukocyte aggregates $^{103}$ in circulation or upon platelet activation ${ }^{104-106}$. In studies of platelet-leukocyte aggregate formation, co-incidence issues need to be taken into account ${ }^{107}$ and distinguished from true aggregates. It also needs to be recognized that platelet-monocyte aggregates form spontaneously after blood collection (see Fig. 1K), so to be useful in a clinical setting, samples need to be fixed immediately after collection ${ }^{103}$ or even with fixation added to the blood collection tube ${ }^{108}$.

Measurements of circulating platelet aggregates or P-selectin-positive platelets have been reported in a number of clinical conditions. However, the rapid shedding of P-selectin on circulating platelets ${ }^{109}$ and the potential risk of spontaneous formation after blood collection complicates the interpretation of the results. Protocols including immediate fixation have been described ${ }^{110}$, and might be a possible solution to this problem. However, activated platelets are supposed to be attached to the site of damage and not circulating. Thus, measurement of receptors being cleaved off from activated platelets, such as soluble P-selectin, sGPVI or sCD40 ligand, might be better alternatives in this context.

\section{Platelet activation}

Platelet activation can be induced by addition of one or more platelet agonists to the diluted blood samples. Agonists can be added in a first separate step or be a part of the antibody mixture in which the blood is diluted. If pre-incubation with antibodies or inhibitors is needed for optimal performance, agonists can also be added in a subsequent step. Platelet aggregate formation can be avoided by a high enough dilution, gentle mixing and incubation in static conditions. Table 2 summarizes platelet agonists and receptor activation pathways amenable to testing by flow cytometry. However, it should be kept in mind that release of granule contents is contributing to the activation response by the more potent agonists. ADP receptor inhibition (especially $P 2 Y_{12}$ ) and presence of apyrase will therefore decrease platelet responses significantly (see Fig. 1G-I). The formation of thromboxane $A_{2}\left(T X A_{2}\right)$ from arachidonic acid seems to be of less importance, as aspirin treatment is often reported not to affect flow cytometry results ${ }^{111-113}$. The reason for this is somewhat unclear, but the lower cell density and absence of shear might be potential explanations. 
The temperature used during activation of platelets will affect the response. The activation step is traditionally performed at room temperature, where higher activation responses are actually seen. It has also been claimed that the PAC- 1 antibody is not stable at $37^{\circ} \mathrm{C}^{114}$, but this is not supported by our data, where pre-incubation of the antibody at $37^{\circ} \mathrm{C}$ did not alter its performance if the experiment was performed at room temperature (see Fig. 1J). Another reason for experiments at room temperature might be that the number of tubes needed for testing of different activation conditions may be cumbersome to handle at $37^{\circ} \mathrm{C}$, but it is possible to use a water bath or similar to perform the activation at other temperatures. In the case of annexin $V$, the binding has been reported to be enhanced at room temperature ${ }^{115}$.

Table 2: Summary of platelet agonists and activation pathways possible to test by flow cytometry. References are only provided for the more uncommon agonists and for information important to consider when using the different agonists.

\begin{tabular}{|c|c|c|}
\hline Platelet agonist & Receptors & Remarks \\
\hline Thrombin & PAR1, PAR4, GPIb/V/IX & $\begin{array}{l}\text { GPRP peptide needed to prevent fibrin } \\
\text { polymerization in PRP/whole blood samples. } \\
\text { Do not use with anticoagulants that inhibit } \\
\text { thrombin. }\end{array}$ \\
\hline PAR1-AP & PAR1 & $\begin{array}{l}\text { The most commonly used and potent peptide } \\
\text { has amino acid sequence SFLLRN }{ }^{116} \text {. Also } \\
\text { called "TRAP" or "TRAP-6". SFLLRN also } \\
\text { activates PAR2 }{ }^{117} \text {, but this receptor is not } \\
\text { present on platelets }{ }^{118} \text {. }\end{array}$ \\
\hline PAR4-AP & PAR4 & $\begin{array}{l}\text { The most used and most active peptide has } \\
\text { amino acid sequence AYPGKF, and is based on } \\
\text { the mouse PAR4 tethered ligand }{ }^{119} \text {. }\end{array}$ \\
\hline ADP & $P 2 Y_{1}, P 2 Y_{12}$ & $\begin{array}{l}\text { Autologous ADP also contributes to the } \\
\text { response of other platelet agonists (see Fig. } \\
1 \mathrm{G}-\mathrm{I} \text { ). }\end{array}$ \\
\hline CRP-XL & GPVI & $\begin{array}{l}\text { Cross-linking is needed for CRP to be active }{ }^{120} \text {. } \\
\text { Fibrillar type I ("Horm") collagen is not an } \\
\text { effective agonist in flow cytometry, although } \\
\text { methylated acid soluble collagen type I is } \\
\text { more potent }^{121} \text {. }\end{array}$ \\
\hline
\end{tabular}




\begin{tabular}{|c|c|c|}
\hline Convulxin & GPVI & $\begin{array}{l}\text { C-type lectin isolated from Crotalus durissus } \\
\text { terrificus snake venom }{ }^{122} \text {. }\end{array}$ \\
\hline Epinephrine (adrenaline) & $\begin{array}{l}\alpha 2 \mathrm{~A} \text {-adrenergic } \\
\text { receptor }\end{array}$ & $\begin{array}{l}\text { Usually only potentiating effects in washed } \\
\text { platelet suspensions, but direct effects in PRP } \\
\text { and whole blood }{ }^{123} \text {. }\end{array}$ \\
\hline U46619 & $\mathrm{TXA}_{2}$ receptor $(\mathrm{TP})$ & $\begin{array}{l}\mathrm{PGH}_{2} \text { analog, potent and stable TP receptor } \\
\text { agonist }{ }^{125} \text {. }\end{array}$ \\
\hline $\begin{array}{l}\text { Rhodocytin } \\
\text { fucoidan } \\
\text { 127 }\end{array}$ & CLEC-2 & $\begin{array}{l}\text { Podoplanin is the physiological ligand for } \\
\text { CLEC- } 2^{128} \text {. }\end{array}$ \\
\hline Serotonin & $5-\mathrm{HT}_{2 \mathrm{~A}}$ & $\begin{array}{l}\text { Reported to enhance activation by other } \\
\text { agonists in whole blood assays }{ }^{129} \text {. }\end{array}$ \\
\hline Arachidonic acid & $\begin{array}{l}\text { TP (after conversion to } \\
\text { TXA }_{2} \text { by COX-1 and } \\
\text { thromboxane } \\
\text { synthetase) }\end{array}$ & $\begin{array}{l}\text { Problems with cell lysis reported, which needs } \\
\text { to be checked and proven not to influence the } \\
\text { results ( } \mathrm{Ca}^{2+} \text { and plasma may be somewhat } \\
\text { protective) })^{26,130-134} \text {. }\end{array}$ \\
\hline Ristocetin & $\begin{array}{l}\text { Induces conformational } \\
\text { changes allowing vWF } \\
\text { to bind to GPIb. }\end{array}$ & $\begin{array}{l}\text { Has been used to design flow cytometry- } \\
\text { based tests for von Willebrand disease }{ }^{135} \text {. } \\
\text { However, problems with cell fragmentation }{ }^{26} \\
\text { and platelet apoptosis }{ }^{136} \text { have been reported. }\end{array}$ \\
\hline
\end{tabular}

5- $\mathrm{HT}_{2 \mathrm{~A}}$ - 5-hydroxytryptamine receptor $2 \mathrm{~A}, \mathrm{ADP}$ - adenosine diphosphate, AP - activating peptide, $\mathrm{Ca}^{2+}$ - calcium, CLEC-2 - C-type lectin-like receptor 2, COX-1 - cyclooxygenase-1, CRP-XL - crosslinked collagen-related peptide, GP - glycoprotein, GPRP - glycyl-L-prolyl-L-arginyl-L-proline, PAR1/4 - protease activated receptor $1 / 4, \mathrm{PGH}_{2}$ - prostaglandin $\mathrm{H}_{2}, \mathrm{PRP}$ - platelet-rich plasma, TRAP thrombin receptor activating peptide, $T x A_{2}-$ Thromboxane $A_{2}$, TP - Thromboxane $A_{2}$ receptor, vWF - von Willebrand factor,

The concentrations of agonists vary between studies, in part due to the choice of anticoagulant, platelet preparation method, etc., but also due to the specific purpose of the study. If the aim is to induce formation of PS-exposing procoagulant platelets, high doses of collagen- and thrombinreceptor activating substances in combination are the most effective stimuli ${ }^{86}$, and presence of calcium and autocrine stimulation by $\mathrm{ADP}^{137}$ are important components.

Studies investigating normal ranges for platelet function in normal donors have shown that the variation is relatively high, especially at low and medium doses of agonists $26,138,139$, and with a considerable overlap in responses between individuals with and without reported bleeding 
problems. Still, recent large studies of patients with platelet function defects using aggregometry suggest that a streamlined protocol with single doses of a number of agonists is enough to identify most patients ${ }^{140,141}$. A similar approach might be considered for flow cytometry studies, where a suggestion is to use a dose where the percentage of platelets exposing an activation marker such as P-selectin (for which a full response can be expected) levels out in normal donors ${ }^{26}$. On the other hand, if the aim is to identify individuals with hyper-reactive platelets, aggregation studies suggest that sub-maximal doses are more indicative ${ }^{142}$. Control samples, where platelets are only treated with buffer, should always be included in the protocol in order to visualize the degree of spontaneous platelet pre-activation. This is commonly done by measuring P-selectin exposure, as this is a sensitive marker for pre-activated platelets that is not reversible in vitro ${ }^{57,143}$. The level of pre-activation should also be reported, and samples showing too high pre-activation levels should be interpreted with caution or if possible excluded from evaluation. Information on the appropriate level to use as a threshold for pre-activation is scarce. It further depends somewhat on the resolution of the flow cytometer used and of course on the aim of the study. Our experience is that an upper threshold of around 15\% P-selectin positive platelets usually identifies samples with an acceptable level of pre-activation.

\section{Stopping the reaction}

The activation is ended after an exact time by addition of a larger volume of buffer to stop the reactions. Direct inhibitors to the platelet agonists used, such as hirudin or apyrase, or a fixative may be added to this stopping solution. In clinical settings, a light formaldehyde fixation (0.5-1\%) is often used to prolong the sample stability before analysis ${ }^{28}$. However, many fluorophores will show lower intensity, and some antigens may be destroyed by fixation. It is therefore important to test and optimize the protocol before starting a study, and keep conditions constant throughout to allow interpretations and comparisons to be done. As fixation affects the platelet membrane properties, it is especially important to verify how fixation affects markers detecting membrane changes, such as PS exposure and formation of microparticles, where fixation may lead to changes wrongly interpreted as being part of the physiological response. In cases where fixation is deemed impossible, flow cytometry analysis needs to be performed as soon as possible, as dilution alone will only keep the samples stable for a shorter period. The maximum time allowed should be tested, applied consistently within the trial participant groups and reported together with the results. 


\section{Analysis}

Results from the analysis can be expressed either as the percentage of cells being positive for the marker, or the median fluorescence intensity (MFI) of the total platelet population. The percentage of positive platelets has been suggested to be advantageous in situations where all cells do not become positive ${ }^{28,144}$, and also due to its assumed transferability between instruments, but only if proper controls are applied to set the boundary between negative and positive platelets, as discussed above. The other alternative is the MFI, which reports the median signal from bound antibody for the total platelet population. This approach will be advantageous in situations where most platelets express the antigen, but where the level of expression could vary between individual $\mathrm{s}^{21}$ or treatments. The geometric mean is an alternative to the median. The mean should not be used as a few highly positive events are often detected, which tend to make the mean unreliable. However, the drawback with MFI in a large clinical study with an extended patient recruitment or follow up period is that the flow cytometer performance may shift with time. Thus, the instrument stability over time needs to be verified for the results to be comparable. Control beads of different kinds are provided by the manufacturers to verify linearity and detector/laser performance over time, and should always be used to monitor instrument performance. As the MFI scaling is arbitrary, it is necessary to run fluorescence calibration beads allowing responses to be reported as Molecules of Equivalent Soluble Fluorochrome (MESF) ${ }^{145}$, if results are to be compared between instruments and over time in e.g. multicenter trials.

For clinical studies aiming to identify and/or diagnose patients with platelet dysfunction, it is essential to establish appropriate reference intervals. The guidelines from the British Society of Haematology for investigation of heritable platelet function disorders recommend that local, normal cut-off values are established using non-parametric statistics, but recognizes that this is not commonly done ${ }^{22}$. Indeed, the intra- and inter-individual variation and the presence of high and low responders among normal donors make this a challenging task. Also, samples from 120 individuals are recommended to create a reference interval using non-parametric methods ${ }^{146}$. However, other approaches such as bootstrap-based procedures ${ }^{147}$ or the robust method described by Horn and Pesce ${ }^{148}$ may enable calculation of reference intervals with a lower number of reference samples ${ }^{146,149}$. 


\section{CURRENT USE OF FLOW CYTOMETRY FOR PLATELET FUNCTION TESTING IN CLINICAL SETTINGS}

\section{Diagnosis of mild bleeding disorders}

A survey regarding the diagnosis of patients with mild bleeding disorders including 202 laboratories in 37 countries was recently reported by the International Society of Thrombosis and Haemostasis $(\text { ISTH })^{150}$. A flow cytometer was available in $57 \%$ of the laboratories. It was used as a first step test in $23 \%$ and as a second step test in approximately two thirds of the laboratories. The main use was to study expression levels of receptors know to be absent in rare inherited platelet disorders such as Glanzmann's thrombastenia and Bernard-Soulier syndrome. 78 of the laboratories used flow cytometry to study alpha granule release, measuring P-selectin exposure upon activation. In addition to that, activation of fibrinogen receptor GPIIb/IIla was relatively common, but only using a few agonists, often ADP and PAR1-AP (TRAP-6), while other tests, such as dense granule release, procoagulant activity or lysosomal release was assessed by less than 30 of the laboratories. Light transmission aggregometry was available in $73 \%$ of the laboratories and used for first line testing in $59 \%$. Notably, out of an estimated number of 14,000 patients investigated each year, no abnormality was found in $60 \%$ of the cases, and only $9 \%$ of the remaining received a definite molecular diagnosis. This indicates that the current battery of tests may be insufficient to indicate where a potential defect is located.

\section{Transfusion medicine}

Flow cytometry has been commonly used in transfusion medicine to investigate the in vitro quality of platelets in platelet concentrates (PCS) during storage and to assess how different preparation and storage conditions affect platelet properties ${ }^{151-154}$. However, most studies have not included any addition of platelet agonists, but studied changes in spontaneous expression of receptors such as $\mathrm{GPIb}^{152,155}$ and GPIIb/IIIa ${ }^{152,156}$, P-selectin ${ }^{154,155}$ or $\mathrm{CD}^{153} 3^{152,155}$ as activation markers and annexin $\mathrm{V}$ as apoptosis marker ${ }^{152}$. Spontaneous increases in P-selectin exposure, annexin V binding and CD63 are often reported, while the receptor expression studies have been showing variable results. Even less is known about the agonist-induced expression and how it is affected by storage. The up-regulation of GPIb (CD42b) and P-selectin after agonist stimulation has been found to decrease during storage $^{157-160}$, as well as the PAC-1 expression ${ }^{161}$. Agonist-induced formation of microparticles and exposure of LAMP-1 was recently suggested as potential new markers to detect deteriorating platelet function during storage ${ }^{54}$. How these findings correlate to in vivo performance of transfused platelets is however still unknown. Only a few studies have investigated the correlation between 
expression of activation markers and in vivo viability and the correlations reported so far have been low and varying between studies ${ }^{162-164}$. Thus investigation of the platelet activation potential using flow cytometry could potentially contribute to better results in this regard.

\section{Anti-platelet drug testing}

One commercial flow cytometry-based test has been developed to measure the function of the platelet $\mathrm{P}_{2} \mathrm{Y}_{12}$ receptor, with the aim to study the effect of anti-platelet drugs targeting this receptor (e.g. clopidogrel, prasugrel, ticagrelor). In the vasodilator-stimulated phosphoprotein (VASP) assay, platelets are incubated with either prostaglandin $E_{1}\left(P E_{1}\right)$ or $A D P+P G E_{1}$, and the phosphorylation state of VASP is measured to determine the degree of active $\mathrm{P} 2 \mathrm{Y}_{12}$ receptor. The test has been compared to other approaches to measure $P 2 \mathrm{Y}_{12}$ inhibition in clinical settings, but the frequency of "non-responders" identified has been shown to vary considerably depending on the assay performed ${ }^{165}$. In addition, the correlations between the assays have been low in several studies ${ }^{166}$. As an alternative to the flow cytometry protocol, an ELISA method for VASP phosphorylation has been developed. This enables testing of plasma samples, thereby making remote testing easier to perform ${ }^{167}$. Direct or indirect methods to detect platelet GPIIb/IIla antagonists, as well as methods based on arachidonic acid to detect aspirin use have been described, but none has gained widespread attention or commercial use. A recent study comparing flow cytometry to other methods to determine platelet function in patients on dual antiplatelet therapy report low correlations between the different arachidonic acid based methods ${ }^{168}$. The above mentioned potential issues with cell lysis by arachidonic acid could be one explanation, but that needs to be further investigated.

\section{Thrombosis and disease risk assessment}

The potential to form procoagulant platelets upon strong activation with thrombin in combination with convulxin or collagen has been measured in a number of disease states. Increased formation of procoagulant platelets (measured as coated platelets) has been reported in thrombotic conditions such as ischemic stroke and transient ischemic attack ${ }^{169-172}$ and lower formation in hemorrhagic conditions such as hemorrhagic stroke ${ }^{173-175}$. However, as these reports originate from a single center, additional studies from independent groups are needed to strengthen these findings. Platelet function tested by flow cytometry was also recently reported to be associated with bleeding severity in children with immune thrombocytopenia (ITP) independent of the platelet count ${ }^{176}$.

Although not being platelet function tests, and with the limitations discussed previously, circulating P-selectin-positive platelets and platelet-leukocyte aggregates have been described in a number of 
conditions as reviewed by Linden et $\mathrm{al}^{177}$, with platelet-leukocyte aggregates being potentially more informative, as P-selectin is rapidly removed from the surface of activated platelets in vivo ${ }^{109}$.

\section{FLOW CYTOMETRY FOR PLATELET FUNCTION TESTING IN CLINICAL SETTINGS - NEW PERSPECTIVES}

Table 3 summarizes advantages and challenges for platelet function testing by flow cytometry in a clinical setting. The major advantage is the possibility to test a number of different aspects of platelet function in a small volume of whole blood and also in thrombocytopenic patients. This together with the increasing availability of flow cytometers and improvements in sample preparation, including new fixation possibilities and pre-made tubes which allows remote site testing ${ }^{108,110,178,179}$, open up interesting future avenues. Especially in the field of mild bleeding disorders, it will be interesting to see if light transmission aggregometry in the future is challenged by flow cytometry for the diagnosis of these patients. Bleeding risk assessment in patients with thrombocytopenia is another interesting future possibility.

For assessment of thrombotic events, the situation is more complicated, as the mechanisms underlying these events are more complex. In case of persistent hypercoagulability or vessel wall problems, it is also important to keep in mind that all ex vivo platelet function studies only will target platelets that are still circulating. This means that a lower platelet activation response could be expected. Indeed, this was the case in a recent study by us, where lower platelet activation was found in circulating platelets in patients infected with hanta-virus with ongoing platelet destruction ${ }^{180}$. For anti-platelet drug testing or in acute settings, flow cytometry may be less useful, as the turn-around time might still be considered too long, despite the improvements regarding sample preparation mentioned above. Furthermore, the potential to use multi-color protocols also means that the data analysis and its interpretation will become increasingly complex. A future challenge may then be to develop and evaluate multi-parameter analysis algorithms with the potential to capture and identify defects and features of platelet functionality that may have diagnostic and/or prognostic potential. 
Table 3: Summary of advantages and limitations/challenges in the development of flow cytometry platelet function testing for clinical use

\begin{tabular}{|l|}
\hline Advantages \\
\hline Tests can be designed to include many different aspects of platelet function and surface \\
expression in a single protocol. \\
\hline Low volumes of blood are needed, which is advantageous in e.g. pediatric patients. \\
\hline $\begin{array}{l}\text { Whole blood can be used, thereby avoiding the risk of losing denser platelet populations or } \\
\text { causing pre-activation by centrifugation steps. }\end{array}$ \\
\hline Platelet function can be evaluated in thrombocytopenic patients. \\
\hline Platelet pre-analytical activation can be easily tested and accounted for. \\
\hline The field is still in its early days. Thus it seems possible that a well-designed and standardized \\
protocol could be adopted by many researchers and diagnostic laboratories. \\
\hline $\begin{array}{l}\text { Limitations/challenges } \\
\text { induced by platelet-platelet-contacts. }\end{array}$ \\
\hline $\begin{array}{l}\text { An increasing number of flow cytometers on the market increase the need for standardization } \\
\text { efforts. }\end{array}$ \\
\hline $\begin{array}{l}\text { The preparation of samples is labor-intensive (but with potential improvements) and a skilled } \\
\text { operator is needed to analyze the obtained results. }\end{array}$ \\
\hline Many proposed protocols are not yet validated by studies of patients with well-defined defects. \\
\hline End-point measurements are usually the only option. \\
\hline Does not include any shear stress component. \\
\hline
\end{tabular}

\section{CONCLUDING REMARKS}

Flow cytometry allows a versatile and sensitive simultaneous testing of a multitude of platelet properties and functions. The high sensitivity requires knowledge of the level of platelet preactivation to be able to interpret the results. But on the other hand, flow cytometry is one of few platelet function tests where this is easily achieved by inclusion of a buffer-treated sample. The method works in thrombocytopenic patients and only requires low volumes of blood. And even though traditional platelet function testing by flow cytometry requires skilled staff and therefore is impractical in many clinical settings, newly introduced and future improvements may well be paving the way for more widespread clinical use. The increasingly challenging analysis needs to be dealt 
with before this can become reality. In addition, there is a need for studies coupling flow cytometry test results to clinical outcomes, and also comparative studies with other tests.

\section{Acknowledgements}

The authors wish to thank Prof. Elvar Theodorsson for valuable advice on statistical methods for reference intervals and Kristina Hasselgren for experimental work on platelet-leukocyte aggregates.

\section{References}

1. Quiroga T, Mezzano D. Is my patient a bleeder? A diagnostic framework for mild bleeding disorders. Hematology Am Soc Hematol Educ Program 2012;2012:466-474

2. Hayward CP, Moffat KA, Pai M, et al. An evaluation of methods for determining reference intervals for light transmission platelet aggregation tests on samples with normal or reduced platelet counts. Thromb Haemost 2008;100(1):134-145

3. Shattil SJ, Cunningham M, Hoxie JA. Detection of activated platelets in whole blood using activation-dependent monoclonal antibodies and flow cytometry. Blood 1987;70(1):307-315

4. Merolla M, Nardi MA, Berger JS. Centrifugation speed affects light transmission aggregometry. Int J Lab Hematol 2012;34(1):81-85

5. Femia EA, Pugliano M, Podda G, Cattaneo M. Comparison of different procedures to prepare platelet-rich plasma for studies of platelet aggregation by light transmission aggregometry. Platelets 2012;23(1):7-10

6. Lyon ME, Fine JS, Henderson PJ, Lyon AW. D-phenylalanyl-L-prolyl-L-arginine chloromethyl ketone (PPACK): alternative anticoagulant to heparin salts for blood gas and electrolyte specimens. Clin Chem 1995;41(7):1038-1041

7. Ginsberg MH, Lightsey A, Kunicki TJ, et al. Divalent cation regulation of the surface orientation of platelet membrane glycoprotein Ilb. Correlation with fibrinogen binding function and definition of a novel variant of Glanzmann's thrombasthenia. J Clin Invest 1986;78(4):1103-1111

8. Lindahl TL, Festin R, Larsson A. Studies of fibrinogen binding to platelets by flow cytometry: an improved method for studies of platelet activation. Thrombosis and Haemostasis 1992;68(2):221-225

9. Storey RF, May JA, Wilcox RG, Heptinstall S. A whole blood assay of inhibition of platelet aggregation by glycoprotein IIb/IIla antagonists: comparison with other aggregation methodologies. Thromb Haemost 1999;82(4):1307-1311.

10. Storey RF, Wilcox RG, Heptinstall S. Differential effects of glycoprotein Ilb/IIla antagonists on platelet microaggregate and macroaggregate formation and effect of anticoagulant on antagonist potency. Implications for assay methodology and comparison of different antagonists. Circulation 1998;98(16):1616-1621

11. Packham MA, Bryant NL, Guccione MA, Kinlough-Rathbone RL, Mustard JF. Effect of the concentration of $\mathrm{Ca} 2+$ in the suspending medium on the responses of human and rabbit platelets to aggregating agents. Thromb Haemost 1989;62(3):968-976

12. Packham MA, Kinlough-Rathbone RL, Mustard JF. Thromboxane A2 causes feedback amplification involving extensive thromboxane $A 2$ formation on close contact of human platelets in media with a low concentration of ionized calcium. Blood 1987;70(3):647-651

13. Wallén $\mathrm{NH}$, Ladjevardi $\mathrm{M}$, Albert J, Broijersen A. Influence of different anticoagulants on platelet aggregation in whole blood; a comparison between citrate, low molecular mass heparin and hirudin. Thrombosis Research 1997;87(1):151-157 
14. Laudano AP, Cottrell BA, Doolittle RF. Synthetic peptides modeled on fibrin polymerization sites. Ann N Y Acad Sci 1983;408:315-329

15. Kawasaki K, Hirase K, Miyano M, Tsuji T, Iwamoto M. Amino acids and peptides. XVI. Synthesis of $\mathrm{N}$-terminal tetrapeptide analogs of fibrin $\alpha$-chain and their inhibitory effects on fibrinogen/thrombin clotting. Chemical and Pharmaceutical Bulletin 1992;40(12):3253-3260

16. Laudano A, Doolittle R. Studies on synthetic peptides that bind to fibrinogen and prevent fibrin polymerization. Structural requirements, number of binding sites, and species differences. Biochemistry 1980;19(5):1013-1019

17. Michelson AD. Platelet activation by thrombin can be directly measured in whole blood through the use of the peptide GPRP and flow cytometry: methods and clinical applications. Blood Coagul Fibrinolysis 1994;5(1):121-131

18. Burgess JK, Chong BH. The platelet proaggregating and potentiating effects of unfractionated heparin, low molecular weight heparin and heparinoid in intensive care patients and healthy controls. Eur J Haematol 1997;58(4):279-285

19. Messmore HL, Jr., Griffin B, Fareed J, Coyne E, Seghatchian J. In vitro studies of the interaction of heparin, low molecular weight heparin and heparinoids with platelets. Ann N Y Acad Sci 1989;556:217-232

20. Kozek-Langenecker SA, Mohammad SF, Masaki T, Kamerath C, Cheung AK. The effects of heparin, protamine, and heparinase 1 on platelets in vitro using whole blood flow cytometry. Anesth Analg 2000;90(4):808-812

21. Michelson AD. Flow cytometry: a clinical test of platelet function. Blood 1996;87(12):49254936

22. Harrison $\mathrm{P}$, Mackie I, Mumford A, et al. Guidelines for the laboratory investigation of heritable disorders of platelet function. Br J Haematol 2011;155(1):30-44

23. Wallin O, Soderberg J, Grankvist K, Jonsson PA, Hultdin J. Preanalytical effects of pneumatic tube transport on routine haematology, coagulation parameters, platelet function and global coagulation. Clin Chem Lab Med 2008;46(10):1443-1449

24. Glas M, Mauer D, Kassas H, Volk T, Kreuer S. Sample transport by pneumatic tube system alters results of multiple electrode aggregometry but not rotational thromboelastometry. Platelets 2013;24(6):454-461

25. Kaiser AF, Neubauer H, Franken CC, et al. Which is the best anticoagulant for whole blood aggregometry platelet function testing? Comparison of six anticoagulants and diverse storage conditions. Platelets 2012;23(5):359-367

26. Rubak P, Nissen PH, Kristensen SD, Hvas AM. Investigation of platelet function and platelet disorders using flow cytometry. Platelets 2015:1-9

27. Ramstrom S, Oberg KV, Akerstrom F, Enstrom C, Lindahl TL. Platelet PAR1 receptor density-correlation to platelet activation response and changes in exposure after platelet activation. Thromb Res 2008;121(5):681-688

28. Schmitz G, Rothe G, Ruf A, et al. European Working Group on Clinical Cell Analysis: Consensus protocol for the flow cytometric characterisation of platelet function. Thromb Haemost 1998;79(5):885-896

29. Shattil SJ, Hoxie JA, Cunningham M, Brass LF. Changes in the platelet membrane glycoprotein Ilb.Illa complex during platelet activation. J Biol Chem 1985;260(20):1110711114

30. Goodall AH, de Oliveira Domingos M, Chronos N, Janes SL, Wilson DJ. Flow cytometric detection of the redistribution of the glycoprotein Ib-IX complex on thrombin-stimulated platelets is dependent on the type of antibody conjugate used. Blood 1993;81(5):1407-1409

31. Hulspas R, O'Gorman MR, Wood BL, Gratama JW, Sutherland DR. Considerations for the control of background fluorescence in clinical flow cytometry. Cytometry B Clin Cytom 2009;76(6):355-364 
32. Maecker HT, Trotter J. Flow cytometry controls, instrument setup, and the determination of positivity. Cytometry A 2006;69(9):1037-1042

33. Giebish G, Windhager E. Transport of urea, glucose, phosphate, calcium, magnesium and organic solutes. In: Boron WF, Boulpaep EL eds, Molecular physiology 2nd Edition. Philadelphia, PA, USA: Saunders Elsevier; 2009

34. Rink TJ, Sage SO. Calcium signaling in human platelets. Annu Rev Physiol 1990;52:431-449

35. Heemskerk JW, Feijge MA, Andree HA, Sage SO. Function of intracellular [Ca2+]i in exocytosis and transbilayer movement in human platelets surface-labeled with the fluorescent probe 1-(4-trimethylammonio)phenyl)-6-phenyl-1,3,5-hexatriene. Biochim Biophys Acta 1993;1147(2):194-204

36. Pasquet JM, Dachary-Prigent J, Nurden AT. Calcium influx is a determining factor of calpain activation and microparticle formation in platelets. Eur J Biochem 1996;239(3):647-654

37. Munnix IC, Kuijpers MJ, Auger J, et al. Segregation of platelet aggregatory and procoagulant microdomains in thrombus formation: regulation by transient integrin activation. Arterioscler Thromb Vasc Biol 2007;27(11):2484-2490

38. Feinman RD, Detwiler TC. Platelet secretion induced by divalent cation ionophores. Nature 1974;249(453):172-173

39. Thiagarajan P, Tait J. Binding of Annexin V/placental anticoagulant protein I to platelets. The Journal of Biological Chemistry 1990;265(29):17420-17423

40. Reutelingsperger CP, Kop JM, Hornstra G, Hemker HC. Purification and characterization of a novel protein from bovine aorta that inhibits coagulation. Inhibition of the phospholipiddependent factor-Xa-catalyzed prothrombin activation, through a high-affinity binding of the anticoagulant to the phospholipids. Eur J Biochem 1988;173(1):171-178

41. Andree HA, Reutelingsperger CP, Hauptmann R, et al. Binding of vascular anticoagulant alpha (VAC alpha) to planar phospholipid bilayers. J Biol Chem 1990;265(9):4923-4928

42. Mann KG, Nesheim ME, Church WR, Haley P, Krishnaswamy S. Surface-dependent reactions of the vitamin K-dependent enzyme complexes. Blood 1990;76(1):1-16

43. Berny-Lang MA, Frelinger III AL, Barnard MR, Michelson AD. Flow Cytometry. In: Michelson AD ed, Platelets (Third Edition). San Diego, CA, USA.: Academic press; 2013:581-602

44. Harrison $P$, Ault KA, Chapman $S$, et al. An interlaboratory study of a candidate reference method for platelet counting. Am J Clin Pathol 2001;115(3):448-459

45. Niccolai E, Emmi G, Squatrito D, et al. Microparticles: Bridging the Gap between Autoimmunity and Thrombosis. Semin Thromb Hemost 2015;41(4):413-422

46. Nomura S, Shimizu M. Clinical significance of procoagulant microparticles. J Intensive Care 2015;3(1):2

47. van der Pol E, Coumans F, Varga Z, Krumrey M, Nieuwland R. Innovation in detection of microparticles and exosomes. J Thromb Haemost 2013;11 Suppl 1:36-45

48. Crompot E, Van Damme M, Duvillier $\mathrm{H}$, et al. Avoiding false positive antigen detection by flow cytometry on blood cell derived microparticles: the importance of an appropriate negative control. PLoS One 2015;10(5):e0127209

49. Freyssinet JM, Toti F. Membrane microparticle determination: at least seeing what's being sized! J Thromb Haemost 2010;8(2):311-314

50. Harrison P, Gardiner C. Invisible vesicles swarm within the iceberg. J Thromb Haemost 2012;10(5):916-918

51. van der Pol E, van Gemert MJ, Sturk A, Nieuwland R, van Leeuwen TG. Single vs. swarm detection of microparticles and exosomes by flow cytometry. J Thromb Haemost 2012;10(5):919-930

52. Bode AP, Hickerson DH. Characterization and quantitation by flow cytometry of membranous microparticles formed during activation of platelet suspensions with ionophore or thrombin. Platelets 2000;11(5):259-271. 
53. Lacroix $R$, Robert $S$, Poncelet $P$, Dignat-George $F$. Overcoming limitations of microparticle measurement by flow cytometry. Semin Thromb Hemost 2010;36(8):807-818

54. Södergren AL, Tynngård N, Berlin G, Ramström S. Responsiveness of platelets during storage studied with flow cytometry - formation of platelet subpopulations and LAMP-1 as new markers for the platelet storage lesion. Vox Sang 2015;Sep 21. doi: 10.1111/vox.12324. [Epub ahead of print]

55. Poncelet $\mathrm{P}$, Robert $\mathrm{S}$, Bouriche $\mathrm{T}$, et al. Standardized counting of circulating platelet microparticles using currently available flow cytometers and scatter-based triggering: Forward or side scatter? Cytometry A 2015

56. Gresele P. Diagnosis of inherited platelet function disorders: guidance from the SSC of the ISTH. J Thromb Haemost 2015;13(2):314-322

57. Michelson AD, Benoit SE, Kroll MH, et al. The activation-induced decrease in the platelet surface expression of the glycoprotein Ib-IX complex is reversible. Blood 1994;83(12):35623573

58. Ginsberg MH, Frelinger AL, Lam SC, et al. Analysis of platelet aggregation disorders based on flow cytometric analysis of membrane glycoprotein IIb-IIla with conformation-specific monoclonal antibodies. Blood 1990;76(10):2017-2023

59. Frelinger AL, 3rd, Cohen I, Plow EF, et al. Selective inhibition of integrin function by antibodies specific for ligand-occupied receptor conformers. J Biol Chem 1990;265(11):63466352

60. Frelinger AL, 3rd, Lam SC, Plow EF, et al. Occupancy of an adhesive glycoprotein receptor modulates expression of an antigenic site involved in cell adhesion. J Biol Chem 1988;263(25):12397-12402

61. Abrams CS, Ellison N, Budzynski AZ, Shattil SJ. Direct detection of activated platelets and platelet-derived microparticles in humans. Blood 1990;75(1):128-138

62. Gralnick HR, Williams SB, McKeown L, et al. Endogenous platelet fibrinogen: its modulation after surface expression is related to size-selective access to and conformational changes in the bound fibrinogen. Br J Haematol 1992;80(3):347-357

63. Zamarron C, Ginsberg MH, Plow EF. Monoclonal antibodies specific for a conformationally altered state of fibrinogen. Thromb Haemost 1990;64(1):41-46

64. Faraday N, Goldschmidt-Clermont P, Dise K, Bray PF. Quantitation of soluble fibrinogen binding to platelets by fluorescence-activated flow cytometry. J Lab Clin Med 1994;123(5):728-740

65. Heilmann E, Hynes LA, Burstein SA, George JN, Dale GL. Fluorescein derivatization of fibrinogen for flow cytometric analysis of fibrinogen binding to platelets. Cytometry 1994;17(4):287-293

66. Schoolmeester A, Vanhoorelbeke K, Katsutani S, et al. Monoclonal antibody IAC-1 is specific for activated alpha2beta1 and binds to amino acids 199 to 201 of the integrin alpha2 Idomain. Blood 2004;104(2):390-396

67. Carmody MW, Ault KA, Mitchell JG, Rote NS, Ng AK. Production of monoclonal antibodies specific for platelet activation antigens and their use in evaluating platelet function. Hybridoma 1990;9(6):631-641

68. Larsen E, Celi A, Gilbert GE, et al. PADGEM protein: a receptor that mediates the interaction of activated platelets with neutrophils and monocytes. Cell 1989;59(2):305-312

69. Stenberg PE, McEver RP, Shuman MA, Jacques YV, Bainton DF. A platelet alpha-granule membrane protein (GMP-140) is expressed on the plasma membrane after activation. J Cell Biol 1985;101(3):880-886

70. Henn V, Slupsky JR, Grafe M, et al. CD40 ligand on activated platelets triggers an inflammatory reaction of endothelial cells. Nature 1998;391(6667):591-594

71. Aiken ML, Ginsberg MH, Plow EF. Mechanisms for expression of thrombospondin on the platelet cell surface. Semin Thromb Hemost 1987;13(3):307-316 
72. Boukerche $\mathrm{H}, \mathrm{McGregor} \mathrm{JL}$. Characterization of an anti-thrombospondin monoclonal antibody (P8) that inhibits human blood platelet functions. Normal binding of P8 to thrombin-activated Glanzmann thrombasthenic platelets. Eur J Biochem 1988;171(1-2):383392

73. Damas C, Vink T, Nieuwenhuis HK, Sixma JJ. The 33-kDa platelet alpha-granule membrane protein (GMP-33) is an N-terminal proteolytic fragment of thrombospondin. Thromb Haemost 2001;86(3):887-893

74. Metzelaar MJ, Heijnen HF, Sixma JJ, Nieuwenhuis HK. Identification of a 33-Kd protein associated with the alpha-granule membrane (GMP-33) that is expressed on the surface of activated platelets. Blood 1992;79(2):372-379

75. Hayward CP, Furmaniak-Kazmierczak E, Cieutat AM, et al. Factor $V$ is complexed with multimerin in resting platelet lysates and colocalizes with multimerin in platelet alphagranules. J Biol Chem 1995;270(33):19217-19224.

76. Hayward CP, Smith JW, Horsewood P, Warkentin TE, Kelton JG. p-155, a multimeric platelet protein that is expressed on activated platelets. J Biol Chem 1991;266(11):7114-7120

77. Wall J, Buijs-Wilts M, Arnold J, et al. A flow cytometric assay using mepacrine for study of uptake and release of platelet dense granule contents. British Journal of Haematology 1985;89:380-385

78. Ramström AS, Fagerberg IH, Lindahl TL. A flow cytometric assay for the study of dense granule storage and release in human platelets. Platelets 1999;10:153-158

79. Gordon N, Thom J, Cole C, Baker R. Rapid detection of hereditary and acquired platelet storage pool deficiency by flow cytometry. Br J Haematol 1995;89(1):117-123

80. Nieuwenhuis HK, van Oosterhout JJ, Rozemuller E, van Iwaarden F, Sixma JJ. Studies with a monoclonal antibody against activated platelets: evidence that a secreted 53,000-molecular weight lysosome-like granule protein is exposed on the surface of activated platelets in the circulation. Blood 1987;70(3):838-845

81. Silverstein RL, Febbraio M. Identification of lysosome-associated membrane protein-2 as an activation-dependent platelet surface glycoprotein. Blood 1992;80(6):1470-1475

82. Israels SJ, McMillan EM, Robertson C, Singhory S, McNicol A. The lysosomal granule membrane protein, LAMP-2, is also present in platelet dense granule membranes. Thromb Haemost 1996;75(4):623-629

83. Nishibori M, Cham B, McNicol A, et al. The protein CD63 is in platelet dense granules, is deficient in a patient with Hermansky-Pudlak syndrome, and appears identical to granulophysin. J Clin Invest 1993;91(4):1775-1782

84. Febbraio M, Silverstein RL. Identification and characterization of LAMP-1 as an activationdependent platelet surface glycoprotein. J Biol Chem 1990;265(30):18531-18537

85. Sodergren AL, Svensson Holm AB, Ramstrom S, et al. Thrombin-induced lysosomal exocytosis in human platelets is dependent on secondary activation by ADP and regulated by endothelial-derived substances. Platelets 2015:1-7

86. Dachary-Prigent J, Freyssinet JM, Pasquet JM, Carron JC, Nurden AT. Annexin V as a probe of aminophospholipid exposure and platelet membrane vesiculation: a flow cytometry study showing a role for free sulfhydryl groups. Blood 1993;81(10):2554-2565

87. Albanyan AM, Murphy MF, Rasmussen JT, Heegaard CW, Harrison P. Measurement of phosphatidylserine exposure during storage of platelet concentrates using the novel probe lactadherin: a comparison study with annexin V. Transfusion 2009;49(1):99-107

88. Dasgupta SK, Guchhait P, Thiagarajan P. Lactadherin binding and phosphatidylserine expression on cell surface-comparison with annexin A5. Transl Res 2006;148(1):19-25

89. Shi J, Heegaard CW, Rasmussen JT, Gilbert GE. Lactadherin binds selectively to membranes containing phosphatidyl-L-serine and increased curvature. Biochim Biophys Acta 2004;1667(1):82-90 
90. Furman MI, Krueger LA, Frelinger AL, et al. GPIIb-IIla antagonist-induced reduction in platelet surface factor $\mathrm{V} / \mathrm{Va}$ binding and phosphatidylserine expression in whole blood. Thromb Haemost 2000;84(3):492-498.

91. Sims PJ, Faioni EM, Wiedmer T, Shattil SJ. Complement proteins C5b-9 cause release of membrane vesicles from the platelet surface that are enriched in the membrane receptor for coagulation factor Va and express prothrombinase activity. J Biol Chem 1988;263(34):18205-18212

92. Holme PA, Brosstad F, Solum NO. Platelet-derived microvesicles and activated platelets express factor Xa activity. Blood Coagul Fibrinolysis 1995;6(4):302-310

93. Gilbert GE, Sims PJ, Wiedmer T, et al. Platelet-derived microparticles express high affinity receptors for factor VIII. J Biol Chem 1991;266(26):17261-17268

94. Schwarz UR, Geiger J, Walter U, Eigenthaler M. Flow cytometry analysis of intracellular VASP phosphorylation for the assessment of activating and inhibitory signal transduction pathways in human platelets--definition and detection of ticlopidine/clopidogrel effects. Thromb Haemost 1999;82(3):1145-1152

95. Dachary-Prigent J, Pasquet JM, Freyssinet JM, Nurden AT. Calcium involvement in aminophospholipid exposure and microparticle formation during platelet activation: a study using Ca2+-ATPase inhibitors. Biochemistry 1995;34(36):11625-11634

96. Assinger A, Volf I, Schmid D. A novel, rapid method to quantify intraplatelet calcium dynamics by ratiometric flow cytometry. PLoS One 2015;10(4):e0122527

97. Davies TA, Drotts D, Weil GJ, Simons ER. Flow cytometric measurements of cytoplasmic calcium changes in human platelets. Cytometry 1988;9(2):138-142

98. Probes for Membrane Potential. In: Johnson I, Spence M eds, The Molecular Probes ${ }^{\circledR}$ Handbook A guide to fluorescent probes and labeling technologies 11th Edition ed. www.lifetechnologies.com/handbook: Life Technologies; 2010:924-936

99. Gyulkhandanyan AV, Mutlu A, Freedman J, Leytin V. Markers of platelet apoptosis: methodology and applications. J Thromb Thrombolysis 2012;33(4):397-411

100. Bernardi P, Scorrano L, Colonna R, Petronilli V, Di Lisa F. Mitochondria and cell death. Mechanistic aspects and methodological issues. Eur J Biochem 1999;264(3):687-701

101. Fox SC, Burgess-Wilson M, Heptinstall S, Mitchell JR. Platelet aggregation in whole blood determined using the Ultra-Flo 100 Platelet Counter. Thromb Haemost 1982;48(3):327-329

102. Tynngard N, Wallstedt M, Sodergren AL, Faxalv L, Ramstrom S. Platelet adhesion changes during storage studied with a novel method using flow cytometry and protein-coated beads. Platelets 2015;26(2):177-185

103. Michelson AD, Barnard MR, Krueger LA, Valeri CR, Furman MI. Circulating monocyte-platelet aggregates are a more sensitive marker of in vivo platelet activation than platelet surface $P$ selectin: studies in baboons, human coronary intervention, and human acute myocardial infarction. Circulation 2001;104(13):1533-1537

104. Izzi B, Pampuch A, Costanzo S, et al. Determinants of platelet conjugate formation with polymorphonuclear leukocytes or monocytes in whole blood. Thromb Haemost 2007;98(6):1276-1284

105. Rinder HM, Bonan JL, Rinder CS, Ault KA, Smith BR. Dynamics of leukocyte-platelet adhesion in whole blood. Blood 1991;78(7):1730-1737

106. Klinkhardt U, Harder S. Flow cytometric measurement of platelet-leukocyte aggregates: a possible target to monitor platelet function? Semin Thromb Hemost 2005;31(4):400-403

107. Bihari P, Fent J, Hamar J, Furesz J, Lakatos S. An easy-to-use practical method to measure coincidence in the flow cytometer--the case of platelet-granulocyte complex determination. J Biochem Biophys Methods 2008;70(6):1080-1085

108. Hagberg IA, Lyberg T. Evaluation of circulating platelet-leukocyte conjugates: a sensitive flow cytometric assay well suited for clinical studies. Platelets 2000;11(3):151-160 
109. Michelson AD, Barnard MR, Hechtman HB, et al. In vivo tracking of platelets: circulating degranulated platelets rapidly lose surface P-selectin but continue to circulate and function. Proc Natl Acad Sci U S A 1996;93(21):11877-11882

110. Hagberg IA, Lyberg T. Blood platelet activation evaluated by flow cytometry: optimised methods for clinical studies. Platelets 2000;11(3):137-150

111. Li N, Hu H, Hjemdahl P. Aspirin treatment does not attenuate platelet or leukocyte activation as monitored by whole blood flow cytometry. Thromb Res 2003;111(3):165-170

112. Rinder CS, Student LA, Bonan JL, Rinder HM, Smith BR. Aspirin does not inhibit adenosine diphosphate-induced platelet alpha-granule release. Blood 1993;82(2):505-512

113. Chronos NA, Wilson DJ, Janes SL, et al. Aspirin does not affect the flow cytometric detection of fibrinogen binding to, or release of alpha-granules or lysosomes from, human platelets. Clin Sci (Lond) 1994;87(5):575-580

114. Scharbert G, Kalb M, Marschalek C, Kozek-Langenecker SA. The effects of test temperature and storage temperature on platelet aggregation: a whole blood in vitro study. Anesth Analg 2006;102(4):1280-1284

115. Ramstrom S, O'Neill S, Dunne E, Kenny D. Annexin V binding to platelets is agonist, time and temperature dependent. Platelets 2010;21(4):289-296

116. Hui KY, Jakubowski JA, Wyss VL, Angleton EL. Minimal sequence requirement of thrombin receptor agonist peptide. Biochem Biophys Res Commun 1992;184(2):790-796

117. Blackhart BD, Emilsson K, Nguyen D, et al. Ligand cross-reactivity within the proteaseactivated receptor family. J Biol Chem 1996;271(28):16466-16471

118. Martorell L, Martinez-Gonzalez J, Rodriguez C, et al. Thrombin and protease-activated receptors (PARs) in atherothrombosis. Thromb Haemost 2008;99(2):305-315

119. Hollenberg MD, Saifeddine M, Sandhu S, Houle S, Vergnolle N. Proteinase-activated receptor-4: evaluation of tethered ligand-derived peptides as probes for receptor function and as inflammatory agonists in vivo. Br J Pharmacol 2004;143(4):443-454

120. Morton LF, Hargreaves PG, Farndale RW, Young RD, Barnes MJ. Integrin alpha 2 beta 1independent activation of platelets by simple collagen-like peptides: collagen tertiary (triplehelical) and quaternary (polymeric) structures are sufficient alone for alpha 2 beta 1independent platelet reactivity. Biochem J 1995;306(Pt 2):337-344

121. Kehrel B, Wierwille S, Clemetson KJ, et al. Glycoprotein VI is a major collagen receptor for platelet activation: it recognizes the platelet-activating quaternary structure of collagen, whereas CD36, glycoprotein Ilb/IIla, and von Willebrand factor do not. Blood 1998;91(2):491-499

122. Polgar J, Clemetson JM, Kehrel BE, et al. Platelet activation and signal transduction by convulxin, a C-type lectin from Crotalus durissus terrificus (tropical rattlesnake) venom via the p62/GPVI collagen receptor. J Biol Chem 1997;272(21):13576-13583

123. Shattil SJ, Budzynski A, Scrutton MC. Epinephrine induces platelet fibrinogen receptor expression, fibrinogen binding, and aggregation in whole blood in the absence of other excitatory agonists. Blood 1989;73(1):150-158

124. Bundy GL. The synthesis of prostaglandin endoperoxide analogs. Tetrahedron Letters 1975;24:1957-1960

125. Morinelli TA, Niewiarowski S, Daniel JL, Smith JB. Receptor-mediated effects of a PGH2 analogue (U 46619) on human platelets. Am J Physiol 1987;253(5 Pt 2):H1035-1043

126. Bergmeier W, Bouvard D, Eble JA, et al. Rhodocytin (aggretin) activates platelets lacking alpha(2)beta(1) integrin, glycoprotein $\mathrm{VI}$, and the ligand-binding domain of glycoprotein Ibalpha. J Biol Chem 2001;276(27):25121-25126

127. Manne BK, Getz TM, Hughes CE, et al. Fucoidan is a novel platelet agonist for the C-type lectin-like receptor 2 (CLEC-2). J Biol Chem 2013;288(11):7717-7726

128. Suzuki-Inoue K, Inoue O, Ozaki Y. The novel platelet activation receptor CLEC-2. Platelets 2011;22(5):380-384 
129. Li N, Wallen NH, Ladjevardi M, Hjemdahl P. Effects of serotonin on platelet activation in whole blood. Blood Coagul Fibrinolysis 1997;8(8):517-523

130. Hubl W, Assadian A, Lax J, et al. Assessing aspirin-induced attenuation of platelet reactivity by flow cytometry. Thromb Res 2007;121(1):135-143

131. Rukoyatkina N, Mindukshev I, Walter U, Gambaryan S. Dual role of the p38 MAPK/cPLA2 pathway in the regulation of platelet apoptosis induced by ABT-737 and strong platelet agonists. Cell Death Dis 2013;4:e931

132. Cohen HJ, Chovaniec ME, Takahashi K, Whitin JC. Activation of human granulocytes by arachidonic acid: its use and limitations for investigating granulocyte functions. Blood 1986;67(4):1103-1109

133. Ts'ao C, Holly CM. Arachidonic acid causes lysis of human platelets in an artificial medium: protection by plasma. Prostaglandins 1979;17(5):775-784

134. Maclouf J, Levy-Toledano S, Savariau E, Hardisty R, Caen JP. Arachidonic acid-induced human platelet aggregation independent of cyclooxygenase and lipoxygenase. Prostaglandins 1984;28(3):383-398

135. Lindahl TL, Fagerberg IH, Larsson A. A new flow cytometric method for measurement of von Willebrand factor activity. Scand J Clin Lab Invest 2003;63(3):217-223

136. Li S, Wang Z, Liao Y, et al. The glycoprotein Ibalpha-von Willebrand factor interaction induces platelet apoptosis. J Thromb Haemost 2010;8(2):341-350

137. Storey RF, Sanderson HM, White AE, et al. The central role of the $\mathrm{P}(2 \mathrm{~T})$ receptor in amplification of human platelet activation, aggregation, secretion and procoagulant activity. Br J Haematol 2000;110(4):925-934.

138. Blais N, Pharand C, Lordkipanidze $\mathrm{M}$, et al. Response to aspirin in healthy individuals. Crosscomparison of light transmission aggregometry, VerifyNow system, platelet count drop, thromboelastography (TEG) and urinary 11-dehydrothromboxane B(2). Thromb Haemost 2009;102(2):404-411

139. Dawood BB, Wilde J, Watson SP. Reference curves for aggregation and ATP secretion to aid diagnose of platelet-based bleeding disorders: effect of inhibition of ADP and thromboxane A(2) pathways. Platelets 2007;18(5):329-345

140. Dawood BB, Lowe GC, Lordkipanidze M, et al. Evaluation of participants with suspected heritable platelet function disorders including recommendation and validation of a streamlined agonist panel. Blood 2012;120(25):5041-5049

141. Watson SP, Lowe GC, Lordkipanidze M, Morgan NV. Genotyping and phenotyping of platelet function disorders. J Thromb Haemost 2013;11 Suppl 1:351-363

142. Yee DL, Sun CW, Bergeron AL, Dong JF, Bray PF. Aggregometry detects platelet hyperreactivity in healthy individuals. Blood 2005;106(8):2723-2729

143. Ruf $\mathrm{A}$, Patscheke $\mathrm{H}$. Flow cytometric detection of activated platelets: comparison of determining shape change, fibrinogen binding, and P-selectin expression. Semin Thromb Hemost 1995;21(2):146-151

144. Goodall AH, Appleby J. Flow-Cytometric Analysis of Platelet-Membrane Glycoprotein Expression and Platelet Activation. In: Gibbins JM, Mahaut-Smith MP eds, Methods in Molecular Biology, vol 272. Totowa, NJ: Humana Press Inc.; 2004:225-236

145. Schwartz A, Gaigalas AK, Wang L, et al. Formalization of the MESF unit of fluorescence intensity. Cytometry B Clin Cytom 2004;57(1):1-6

146. CLSI. Defining, Establishing, and Verifying Reference Intervals in the Clinical Laboratory: Approved Guideline EP28-A3c. . Wayne, PA: Clinical and Laboratory Standards Institute; 2008

147. Linnet K. Nonparametric estimation of reference intervals by simple and bootstrap-based procedures. Clin Chem 2000;46(6 Pt 1):867-869

148. Horn PS, Pesce AJ, Chemistry AAfC. Reference intervals : a user's guide. Washington DC: AACC Press; 2005 
149. Siest G, Henny J, Grasbeck R, et al. The theory of reference values: an unfinished symphony. Clin Chem Lab Med 2013;51(1):47-64

150. Gresele P, Harrison P, Bury L, et al. Diagnosis of suspected inherited platelet function disorders: results of a worldwide survey. J Thromb Haemost 2014;12(9):1562-1569

151. Hagberg IA, Akkok CA, Lyberg T, Kjeldsen-Kragh J. Apheresis-induced platelet activation:comparison of three types of cell separators. Transfusion 2000;40(2):182-192

152. Johnson L, Loh YS, Kwok M, Marks DC. In vitro assessment of buffy-coat derived platelet components suspended in SSP+ treated with the INTERCEPT Blood system. Transfus Med 2013;23(2):121-129

153. Metcalfe $P$, Williamson $L M$, Reutelingsperger $C P$, et al. Activation during preparation of therapeutic platelets affects deterioration during storage: a comparative flow cytometric study of different production methods. Br J Haematol 1997;98(1):86-95.

154. Zhang JG, Carter CJ, Culibrk B, et al. Buffy-coat platelet variables and metabolism during storage in additive solutions or plasma. Transfusion 2008;48(5):847-856

155. Krailadsiri P, Seghatchian J. Are all leucodepleted platelet concentrates equivalent? Comparison of Cobe LRS Turbo, Haemonetics MCS+ LD, and filtered pooled buffy-coatderived platelets. Vox Sang 2000;78(3):171-175

156. Sandgren $\mathrm{P}$, Saeed K. Storage of buffy-coat-derived platelets in additive solution: in vitro effects on platelets of the air bubbles and foam included in the final unit. Blood Transfus 2011;9(2):182-188

157. Apelseth TO, Bruserud O, Wentzel-Larsen T, et al. In vitro evaluation of metabolic changes and residual platelet responsiveness in photochemical treated and gamma-irradiated singledonor platelet concentrates during long-term storage. Transfusion 2007;47(4):653-665

158. Lozano ML, Rivera J, Gonzalez-Conejero R, Moraleda JM, Vicente V. Loss of high-affinity thrombin receptors during platelet concentrate storage impairs the reactivity of platelets to thrombin. Transfusion 1997;37(4):368-375

159. Picker SM, Schneider V, Gathof BS. Platelet function assessed by shear-induced deposition of split triple-dose apheresis concentrates treated with pathogen reduction technologies. Transfusion 2009;49(6):1224-1232

160. Wang C, Mody M, Herst R, Sher G, Freedman J. Flow cytometric analysis of platelet function in stored platelet concentrates. Transfus Sci 1999;20(2):129-139

161. Sandgren $P$, Meinke $S$, Eckert $E$, et al. Random aggregates in newly produced platelet units are associated with platelet activation and release of the immunomodulatory factors SCD40L and RANTES. Transfusion 2014;54(3):602-612

162. Holme S, Sweeney JD, Sawyer S, Elfath MD. The expression of p-selectin during collection, processing, and storage of platelet concentrates: relationship to loss of in vivo viability. Transfusion 1997;37(1):12-17

163. Rinder HM, Murphy M, Mitchell JG, et al. Progressive platelet activation with storage: evidence for shortened survival of activated platelets after transfusion. Transfusion 1991;31(5):409-414

164. Rinder HM, Smith BR. In vitro evaluation of stored platelets: is there hope for predicting posttransfusion platelet survival and function? Transfusion 2003;43(1):2-6

165. Mallouk N, Labruyere C, Reny JL, et al. Prevalence of poor biological response to clopidogrel: a systematic review. Thromb Haemost 2012;107(3):494-506

166. Gorog DA, Fuster V. Platelet function tests in clinical cardiology: unfulfilled expectations. J Am Coll Cardiol 2013;61(21):2115-2129

167. Jakubowski JA, Bourguet N, Boulay-Moine D, et al. Comparison of a new ELISA assay with the flow cytometric assay for platelet vasodilator-associated stimulated phosphoprotein (VASP) phosphorylation in whole blood to assess P2Y(12) inhibition. Thromb Haemost 2012;107(2):388-395 
168. Gremmel T, Koppensteiner R, Panzer S. Comparison of Aggregometry with Flow Cytometry for the Assessment of Agonists -Induced Platelet Reactivity in Patients on Dual Antiplatelet Therapy. PLoS One 2015;10(6):e0129666

169. Kirkpatrick AC, Stoner JA, Dale GL, Prodan Cl. Elevated coated-platelets in symptomatic large-artery stenosis patients are associated with early stroke recurrence. Platelets 2014;25(2):93-96

170. Kirkpatrick AC, Tafur AJ, Vincent AS, Dale GL, Prodan Cl. Coated-platelets improve prediction of stroke and transient ischemic attack in asymptomatic internal carotid artery stenosis. Stroke 2014;45(10):2995-3001

171. Prodan $\mathrm{Cl}$, Dale GL. Coated-platelets in ischemic stroke - potential insight into the etiology of stroke subtypes. Int J Stroke 2008;3(4):249-250

172. Prodan $\mathrm{Cl}$, Vincent AS, Dale GL. Coated-platelet levels are elevated in patients with transient ischemic attack. Transl Res 2011;158(1):71-75

173. Prodan $\mathrm{Cl}$, Stoner JA, Cowan LD, Dale GL. Lower coated-platelet levels are associated with early hemorrhagic transformation in patients with non-lacunar brain infarction. J Thromb Haemost 2010;8(6):1185-1190

174. Prodan $\mathrm{Cl}$, Vincent AS, Dale GL. Coated platelet levels correlate with bleed volume in patients with spontaneous intracerebral hemorrhage. Stroke 2010;41(6):1301-1303

175. Prodan $\mathrm{Cl}$, Vincent AS, Padmanabhan R, Dale GL. Coated-platelet levels are low in patients with spontaneous intracerebral hemorrhage. Stroke 2009;40(7):2578-2580

176. Frelinger AL, 3rd, Grace RF, Gerrits AJ, et al. Platelet function tests, independent of platelet count, are associated with bleeding severity in ITP. Blood 2015;126(7):873-879

177. Linden MD, Frelinger AL, 3rd, Barnard MR, et al. Application of flow cytometry to platelet disorders. Semin Thromb Hemost 2004;30(5):501-511

178. Dovlatova N, Lordkipanidze M, Lowe GC, et al. Evaluation of a whole blood remote platelet function test for the diagnosis of mild bleeding disorders. J Thromb Haemost 2014;12(5):660-665

179. Dovlatova N, May JA, Fox SC. Remote platelet function testing - Significant progress towards widespread testing in clinical practice. Platelets 2015;26(5):399-401

180. Connolly-Andersen AM, Sundberg E, Ahlm C, et al. Increased thrombopoiesis and platelet activation in hantavirus infected patients. J Infect Dis 2015;DOI 10.1093/infdis/jiv161 


\section{Figure legends:}

Fig. 1. Experimental conditions affecting results of platelet function testing by flow cytometry.

Platelets from whole blood (1:12 dilution) were activated with Protease-activated-receptor 1activating peptide (PAR1-AP), cross-linked collagen-related peptide (CRP-XL), adenosine diphosphate (ADP) or vehicle control (C) for 10 minutes at room temperature (RT) unless otherwise indicated. Data are presented as mean \pm standard error of the mean, $n=4-5$. For statistical comparisons, repeated measures ANOVA followed by Bonferroni's multiple comparison test was used. Statistically significant differences are indicated by $*$ or \# if $p<0.05,{ }^{* *}$ or \#\# if $p<0.01$ and $* * *$ or \#\#\# if $p<$ 0.001 .

A-C: Effect of different anticoagulants (citrate, heparin, and hirudin) on platelet activation responses. Median fluorescence intensity (MFI) of (A) PAC-1, (B) P-selectin and (C) \% of platelets exposing lysosomal associated membrane protein-1 (LAMP-1). */\# compared to the corresponding citrate/heparin samples.

D-F: Effect of the absence/presence of $1.5 \mathrm{mM}$ calcium $\left(\mathrm{Ca}^{2+}\right)$ in the buffer on platelet activation. MFI of (D) PAC-1, (E) P-selectin and (F) \% of platelets exposing LAMP-1. * compared to the corresponding sample without $\mathrm{Ca}^{2+}$.

G-I: Effect of autocrine ADP on platelet activation. ADP was degraded by addition of apyrase (grade VII, $0.25 \mathrm{U} / \mathrm{ml}$ ). MFI of (G) PAC-1, (H) P-selectin and (I) \% of platelets exposing LAMP-1. * compared to the corresponding sample without apyrase.

J: Effect of temperature on the MFI of PAC-1, an anti-fibrinogen antibody and P-selectin. The antibody mixture was preincubated at RT or $37^{\circ} \mathrm{C}$ (10 mins). Platelet activation with PAR1-AP was then performed at RT or $37^{\circ} \mathrm{C} .{ }^{*}$ compared to the corresponding sample activated at $37^{\circ} \mathrm{C}$.

K: Percentage of leukocyte-platelet aggregates (detected as \% of leukocytes positive for a GPIIbantibody) at different time points after blood collection. * compared to the corresponding sample analyzed immediately. 
Figure 1:
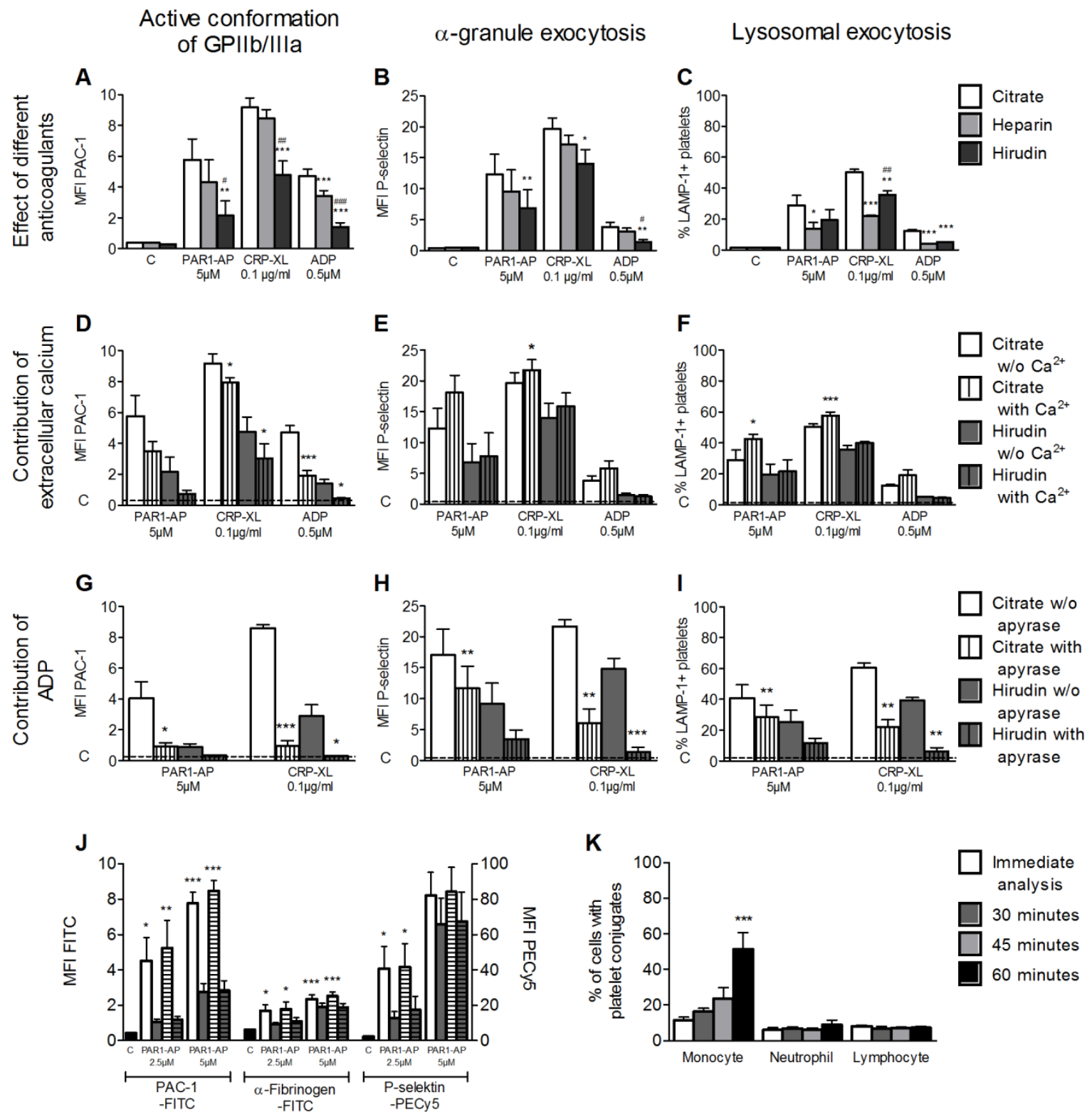

$\square$ Immediate analysis

$\square 30$ minutes

$\square 45$ minutes

\ 60 minutes

Preincubation+ $\square R T+R T \quad$ @ $37^{\circ} \mathrm{C}+\mathrm{RT}$

stimulation temp. $\square R T+37^{\circ} \mathrm{C}$ 目 $37^{\circ} \mathrm{C}+37^{\circ} \mathrm{C}$ 